Arab World English Journal (AWEJ) Special Issue on Covid 19 Challenges April 2021

DOI: https://dx.doi.org/10.24093/awej/covid.24

\title{
Formation of the Culture of Working with Information in the Conditions of Distance Learning During the Covid-19 Pandemic
}

\author{
Oleksandra Markiv \\ Department of Journalism, National Pedagogical Dragomanov University, \\ Kyiv, Ukraine
}

\section{Oksana Zarivna}

Department of English for Engineering \# 2,

National Technical University of Ukraine "Igor Sikorsky Kyiv Polytechnic Institute", Kyiv, Ukraine

\section{Nataliia Khymai}

Department of English for Engineering \# 2,

National Technical University of Ukraine "Igor Sikorsky Kyiv Polytechnic Institute", Kyiv, Ukraine

\section{Natalia Shalova}

Department of English for Engineering \# 2,

National Technical University of Ukraine "Igor Sikorsky Kyiv Polytechnic Institute", Kyiv, Ukraine

Received: $2 / 22 / 2021$

Published:4/26.2021

\section{Abstract}

The main purpose of the study predetermines the main issue of the article: to show the importance of formation of a culture of working with information among students during distance learning, which means the ability to evaluate, perceive information, prevent manipulation, distinguish truth from falsehood. The main task is to assess the existing and desired level of this competence, to develop an organizational model of its formation which consists of the following components: goals and objectives, pedagogical conditions and evaluation criteria. The model was implemented simultaneously at the Drahomanov National Pedagogical University and National Technical University of Ukraine "Igor Sikorsky Kyiv Polytechnic Institute" by teachers of humanities in experimental and control groups (16 people) in three stages: ascertaining, formative and final. A questionnaire and a self-assessment map of the formation of the culture of working with information were developed for the ascertaining stage; purposeful work with students was conducted (special tasks, discussion conversations, discussions) at the formative stage the results before and after the experiment were compared at the final stage in particular. Positive dynamics in the experimental group was noted, the average rate of formation increased. The proposed evaluation criteria - motivational, cognitive and activity ones have demonstrated practical value. It is advisable to recommend their use at other faculties. It is concluded that the organizational model is effective. The prospect of the study is the scientific substantiation of the implementation of the model among a wider range of students and the development of a distance specialized course.

Keywords: culture of working with information, distance learning, educational process, media culture, pedagogical conditions, students.

Cite as: Markiv, O., Zarivna, O., Khymai, N., \& Shalova, N. (2021). Formation of the Culture of Working with Information in the Conditions of Distance Learning During the Covid-19 Pandemic. Arab World English Journal (AWEJ) Special Issue on Covid 19 Challenges (1) DOI: https://dx.doi.org/10.24093/awej/covid.24 
Arab World English Journal (AWEJ) Special Issue on Covid 19 Challenges April 2021

Markiv, Zarivna, Khymai \& Shalova

\section{Introduction}

Proper understanding of the information necessary to form knowledge is extremely important. Moreover, it is also a key point in the preparation of homework and performing independent creative and research work in conditions of distance learning. Considering scientific sources, everything is clear: here the facts are reliable, confirmed and substantiated. If you need to use media materials, there might be problems, because there are too many fakes, misinformation, propaganda and manipulative texts. Such information is inaccurate. It requires additional verification, assessment of contexts, scientific basis or explanation. As Plakhta (2017) says, "unfortunately, we all consume fakes to some extent. However, to encounter manipulation does not mean to believe in it. It's important to be able to recognize media manipulation that can be encountered anywhere" (p. 1).

The Covid-19 pandemic has challenged university education around the world. It transformed pedagogical activity and intensified innovative processes in the organization of education, forced to look for alternative models of cooperation between teachers and students, made distance learning to be the main educational mode. There was a replacement of interactive, personality-oriented traditional classroom learning, in which the teacher had more opportunities to explain the incomprehensible things and get a face-to-face reaction from students, to online education with maximum use of the Internet (involving various web servers, platforms, resources and social networks). Everything seems to be fine: modernizing education is just in time, because the mobile and global world requires a change in management and learning, improving learning opportunities even when, under certain conditions, the student can not be actually present in the classroom. Technology makes it possible to do it. Therefore, we appreciate it. However, having our own teaching experience at the university, we note that distance learning requires a teacher and student to be more focused when working with information. When discussing how to teach English, there are also important points: understanding the terms, the authenticity of the material, where it is placed and if it is translated correctly; if the information is authentic, how to interpret vocabulary and jargonisms properly, and, of course, checking the facts to avoid manipulation by substituting concepts.

The culture of working with information as competence in media society is extremely important. Information flows are growing rapidly every day. There are many unreliable, unverified, obviously fake, as well as purposefully manipulative texts among the array of information. Being incompetent, it is easy to get confused and not to distinguish if it is the truth or lie. There are a lot of destructive sources of information on the Internet. The problem is complicated by the fact that in conditions of distance learning teachers often give students the task to process media material independently and to create their own text because they realize that it is interesting, and they can be encouraged to study the subject in such away. It is extremely important to motivate future professionals to treat information responsibly, check it in several sources, determine manipulative and propaganda narratives. According to the Eismunt (2016), "The use of fact-checking, i.e. verification of allegations for completeness, accuracy and manipulation, does not only protects society from lies but also helps to develop critical thinking among people" (p.1). 
Arab World English Journal (AWEJ) Special Issue on Covid 19 Challenges April 2021

\section{Literature Review}

The issue of media culture, the culture of working with information has recently become very relevant. The area of research interests includes media campaigns, wars, manipulations, the basics of media culture, the role and importance of the pedagogical process in the formation of the culture of information production and consumption. Issues of media culture and media literacy were investigated by many foreign researchers, such as Buckingham (2003); Jolls \& Wilson (2014); Schultz-Jones (2016); Adams (2018); Mason, Krutka \& Stoddard (2018); Bulger \& Davison (2018); Tornero, Tayie, Tejedor \& Pulido (2018); Cubbage (2018); Simmons (2019); McDougall (2019); Šuminas \& Jastramskis (2020); Higdon (2020).

Some domestic researchers emphasize on the use of information in media campaigns as a means of war, as a technique of manipulative influence to do harm to the enemy. For example, Pocheptsov (2013) describes content wars that cover everything: both virtual and cognitive environments and they also program the media environment of a person. The model of the world forms the media flows that people use directly and indirectly. Another researcher Petryk (2009) analyzes special media campaigns and he believes it has the following features: directing or targeting a clearly defined audience; avalanche-like nature of the growth of messages on a particular topic; sensational, tendentious and emotional ways of discussing them.

There are similar views among scholars on the foundations of media culture in terms of socio-cultural and philosophical aspects. Blyzniuk and Kolyada (2000) note that the basis of media culture can be knowledge about the media environment, the laws of its functioning, the ability to navigate in media flows.

We agree with the idea of the importance of the pedagogical process in the formation of the culture of media production and consumption. Scientists Blystiv and Galaz (2015) note that "education is of great importance in the formation of media culture, which should form a new specialist of the media community, who has such skills as information differentiation; development of information evaluation criteria; creation of information and its use" (p.17). Another researcher Levshin (2002) believes that

achieving the goal of media culture formation is conducted in the process of solving the following tasks: the study of various sources of information; mastering the methods of analytical and synthetical processing of educational information, techniques and means of independent search of information in accordance with the tasks that arise during learning; study and application of the possibilities of the newest information technologies, etc. (p.73).

Markiv and Zarivna (2019) also speak on the formation of a culture of working with information in the educational environment through the introduction of media literacy: "Media educators are trying to find ways to teach students not to depend on the information, to consume and assimilate only relevant and necessary information" (p. 170). 
Arab World English Journal (AWEJ) Special Issue on Covid 19 Challenges April 2021

\section{Methods}

The following tasks were chosen for the study:

1. To analyze the need to develop skills of a culture of working with information, proper information consumption, especially in the distance learning mode.

2. To assess the feasibility of using an organizational model for developing this competence, which includes the following components: purpose and goals; pedagogical conditions; criteria of formation.

3. To conduct a pedagogical experiment on the formation of the culture of working with information and evaluate its results.

To fulfil the tasks a set of methods was used, namely: theoretical method comprising analysis of professional literature, classification and systematization of theoretical and experimental data, theoretical modelling of the process of formation of a culture of working with information in terms of distance learning during the Covid-19 pandemic; empirical methods of collecting information (questionnaires, testing, interviews, pedagogical observation, discussion of completed tasks), which contributed to the study of the state and implementation of the research problem, pedagogical experiment (ascertaining, formative, final stages) in order to test the effectiveness of the hypothesis and the effectiveness of experimental work; methods of mathematical statistics used to process the data of the pedagogical experiment, to check the probability of the obtained research results.

\section{Participants}

Drahomanov National Pedagogical University and National Technical University of Ukraine "Igor Sikorsky Kyiv Polytechnic Institute" were selected as an experimentation facility of the study. Experimental and control groups (16 students: 8 technical students, 8 humanities students) were formed. Humanities teachers simultaneously worked remotely with these groups while teaching journalism and philology.

\section{Tools}

The training was conducted remotely on the platforms: Zoom, Google meet, Moodle; digital documents circulation was used as well. A map of self-assessment of the formation of the culture of working with information (15 positions), questionnaires for checkpoints before and after the experiment, testing to identify the level of awareness of students on the need to form a culture of working with information.

Special tools: special tools were used - systematic, communicative, reflective methods, methods of survey, observation, self-assessment, content analysis, rank correlation of Spearman, Student, clarification, interpretation, dialogue, role-playing games, discussions, conversations, interviews and other techniques.

\section{Data Collection Procedure}

The study was conducted during 2020, which was a crucial point for the education system because e-learning became the only way of learning, and covered three stages of scientific and pedagogical research. 
The first stage is the determination of the starting points of the research: goals and objectives, object, subject, hypothesis, research methodology; review of the literature and study of the state of development of the problem on the formation of a culture of working with information; definition, substantiation and development of methods of ascertaining and formative experiments.

The second stage is aimed at the preparation and conduction of ascertaining and formative experiments in order to study the state of formation of the culture of working with information among students.

The third stage is the analysis, generalization and systematization of the obtained empirical data and drawing conclusions.

Let's explain the key definitions for understanding the aspect of our study. Thus, generally speaking, media culture characterizes a degree of perfection of society or a certain part of it in all possible types of working with information: its receipt, accumulation, any kind of processing, creation of new qualitative information, its transfer and practical use (Shelestova, 2016). The basis of media campaigns is the purposeful use of information messages, manipulation buttons, distribution of topics, fakes, the substitution of concepts, misinformation, etc. They have become a means of media war and manipulative technologies. A conscious desire to verify information provides the formation of critical thinking skills, the ability to distinguish truth from lie and withstand media hype, and also to be very responsible in the choice and analysis of media resources. All these features are included in the concept of "media culture" which means conscious, humane and honest use of the system of stable value orientations, beliefs and qualitative characteristics of professional standards within working with information. In fact, this concept determines the content of awareness. When preparing the article for writing, we monitored what media skills modern youth do not have, namely: "skills on finding and preparing information", "resistance to manipulation", "verification of sources", "language training", "knowledge of modern terminology, "working with social networks", "mastering the latest formats of information", "communication skills with people from vulnerable groups", "good knowledge of foreign languages" (Dachkovska, 2016, p. 4).

Thus, the issue of forming a culture of working with information is a pedagogical problem. Therefore, it is advisable to use the following organizational model in the educational process for the cycle of humanitarian, theoretical information disciplines developed by Markiv (2018):

Objective and goals: to determine the content and list of competencies, skills and abilities that justify the system of a culture of working with information (mentioned above).

\section{Pedagogical Conditions}

1) Comprehensive motivation of educational activities of future professionals to the formation of cultural competence within working with information, for example, a search of primary sources, check of actual material, etc.; monitoring of sources of propaganda to prevent false information or its interpretation, especially on the Internet; ability to apply public exposure of the propaganda narrative; use of fact-checking, etc. It is important to emphasize that such 
competence will help students not to fall into the trap of propaganda, not to be exposed to the harmful effects of information, not to pay attention to manipulation or misunderstanding.

2) Structuring the content of preparing students for understanding the content and mechanisms of media competence. As part of the experiment, the following courses were introduced into the course of the humanities university "Mass Media in the World Media Space": a) Mass media and the general public (argument: how mass media affect groups of people); b) means of influencing public opinion (argument: methods of manipulation are revealed); c) techniques and means of media war (argument: the technology of intervention of the subject of counterstrategy into consciousness is revealed). At the technical university, teachers offered students to study authentic mass media materials and translated versions at English classes, as well as posts on social networks. They tried to define the competency level of students in understanding, interpreting, analyzing information on authenticity, ideological bias, falsehood, the substitution of concepts, etc. through a survey.

3) The use of active available methods in the mode of distance learning which provide the formation and development of skills within working with information. It is advisable to use problematic, comparative, retrospective analysis, conversation, i.e. it is necessary not only to explain but also to analyze the content of manipulative content considering components with students immediately (fakes, alternative facts, etc.), as well as to learn to check information from various sources.

\section{Formedness Criteria}

1) Value and motivation criterion is manifested in a positive attitude, the interest of future specialists in the formation of personal culture within working with information. If the communication environment is properly organized, this criterion will be clearly visible.

2) Cognitive criterion denotes the volume, completeness, depth, systematization of professional knowledge on this issue. It can be seen in the written answers of students.

3) Activity criterion is an ability to apply the acquired knowledge in practice.

The experiment was planned to be conducted in three stages: ascertaining stage (measuring the existing level of formation of the culture of working with information); formative stage (formation of the culture of working with information); final stage (measuring the levels of formation of the culture of working with information after the experiment). Conducting experiment in conditions of distance learning, we paid less attention to the first stage, since we understand that such competence is almost non-existent in our society, because media literacy, which is able to form it, is just being introduced. We focused mainly on the formative stage, i.e. the teacher's explanation, skills' training and students' independent work. The experiment was conducted simultaneously at National Pedagogical Dragomanov University and National Technical University of Ukraine "Igor Sikorsky Kyiv Polytechnic Institute" by the teachers of the humanities. Two groups were organized: one experimental and one control group of the 1st year master students on the basis of both universities. Then we combined them and listed the figures in the tables.

It should be noted that the use of learning material on a thematic basis has more informative value. Being well informed does not mean being competent. We selected training material purposefully, and also encouraged the processing the authentic English texts. Actually, there were articles by foreign authors of foreign media, which students evaluated 


\section{Arab World English Journal (AWEJ) Special Issue on Covid 19 Challenges April 2021}

by comparison. They used texts focused on the formation of competence, as well as authentic texts.

Using the technique of questionnaires, we selected questions that would reveal the need to form a culture of working with information. We also conducted two check values. The first diagnostic check value was performed by us at the beginning of the formative stage of the experiment, the second one was done after its completion. Here are some questions we offered students to answer: Do you have enough knowledge, skills and abilities to understand what is written? What do you know about propaganda and manipulation? Do you need a further explanation of what you read? Do you often observe a contradiction between the author's opinion and his own worldview (background knowledge)? Do you feel emotional tension after reading? etc. As a result of the survey, we obtained the following dynamics of awareness of future philologists with the culture of working with information of the experimental and control groups which is presented in table 1.

Table 1. Dynamics of levels of awareness with the culture of working with information of the experimental and control groups (\%)

\begin{tabular}{|l|c|c|c|c|}
\hline \multicolumn{1}{|c|}{ Levels of awareness } & \multicolumn{2}{c|}{ Experimental group } & \multicolumn{2}{c|}{$\begin{array}{c}\text { Control group } \\
\text { CG }\end{array}$} \\
\hline & 1-st check value & 2-nd check value & 1-st check value & 2-nd check value \\
\hline 1 High & 12,5 & 44,3 & 11,5 & 14,5 \\
\hline 2. Moderate & 45,8 & 49,6 & 45,7 & 53,1 \\
\hline 3. Low & 31,7 & 6,1 & 42,7 & 33,4 \\
\hline
\end{tabular}

As can be seen from the table, students' awareness of the importance and content of the culture of working with information increased from the first and second check values in EG by $31.8 \%$ of high level (from $12.5 \%$ to $44.3 \%$ ), by $3.8 \%$ of average level (from $45.8 \%$ to $49.6 \%$ ) and decreased by $25.6 \%$ of low level (from $31.7 \%$ to $6.1 \%$ ). The analysis revealed an insufficient level of culture of working with the information confirmed by the results.

Table 2. Comparison of student test results before and after the experiment (\%)

\begin{tabular}{|c|c|c|c|c|c|c|}
\hline Group & \multicolumn{3}{|c|}{$\mathrm{EG}$} & \multicolumn{3}{|c|}{$\mathrm{CG}$} \\
\hline № & Name, Surname & $\begin{array}{c}\text { Pre- } \\
\text { experimen } \\
\text { tal check } \\
\text { value }\end{array}$ & $\begin{array}{c}\text { Post- } \\
\text { experiment } \\
\text { al check } \\
\text { value }\end{array}$ & Name, Surname & $\begin{array}{c}\text { Pre- } \\
\text { experim } \\
\text { ental } \\
\text { check } \\
\text { value }\end{array}$ & $\begin{array}{l}\text { Post- } \\
\text { experimental } \\
\text { check value }\end{array}$ \\
\hline 1. & Humanities student & 73 & 97 & Humanities student & 58 & 71 \\
\hline 2. & Humanities student & 61,5 & 84,7 & Humanities student & 47 & 69,2 \\
\hline 3. & Humanities student & 73,5 & 86,5 & Humanities student & 39 & 52.5 \\
\hline 4. & Humanities student & 54 & 80,7 & Humanities student & 53 & 70 \\
\hline 5. & Humanities student & 67,4 & 87,9 & Humanities student & 73 & 76 \\
\hline 6. & Humanities student & 69,4 & 85,7 & Humanities student & 75 & 78 \\
\hline 7. & Humanities student & 81,5 & 96,6 & Humanities student & 71 & 81 \\
\hline 8. & Humanities student & 76 & 92 & Humanities student & 74 & 77,5 \\
\hline 9. & Technical student & 75 & 87 & Technical student & 57 & 76,3 \\
\hline 10. & Technical student & 70,9 & 99 & Technical student & 50 & 74 \\
\hline 11. & Technical student & 66,7 & 88,4 & Technical student & 70 & 78,5 \\
\hline
\end{tabular}


Arab World English Journal (AWEJ) Special Issue on Covid 19 Challenges April 2021

Markiv, Zarivna, Khymai \& Shalova

\begin{tabular}{|c|l|c|c|l|c|c|}
\hline 12. & Technical student & 59,3 & 85 & Technical student & 54 & 69,1 \\
\hline 13. & Technical student & 67,5 & 87 & Technical student & 55 & 62 \\
\hline 14. & Technical student & 78,8 & 87,5 & Technical student & 46 & 59 \\
\hline 15 & Technical student & 68,7 & 89,7 & Technical student & 69,7 & 81,2 \\
\hline 16. & Technical student & 70,9 & 99 & Technical student & 50 & 74 \\
\hline
\end{tabular}

Since the survey was conducted anonymously, we encrypted the names of the students and recorded them as a humanities student (eight students) and a technical student (eight students) in both groups. The values to be checked are important for us.

The increment of the average coefficient of the educational level of future specialists, calculated on the basis of pre- and post-experimental check values, is given in table 3.

Table 3. The summary results of testing students before and after the experiment on the formation of the culture of working with information (\%)

\begin{tabular}{|c|c|c|c|}
\hline Group & $\begin{array}{c}\text { Pre-experimental check } \\
\text { value }\end{array}$ & $\begin{array}{c}\text { Post-experimental check } \\
\text { value }\end{array}$ & Incremental value \\
\hline CG & 55,77 & 61,92 & 6,15 \\
\hline EG & 69,61 & 88,93 & 19,32 \\
\hline
\end{tabular}

To confirm the difference between average values of the test results of the experimental group before the experiment and after the experiment, to find out whether these averages are statistically significantly different from each other, in our study:

$\bar{x}_{1}=69,61 ; \bar{x}_{2}=88,93$. To calculate these values we apply the Student $\mathrm{t}$-test $(\mathrm{t})$ by the formula:

$$
t=\frac{\left|\bar{x}_{1}-\bar{x}_{2}\right|}{\sqrt{\left|m_{1}^{2}+m_{2}^{2}\right|}}, \text { where } m_{1} \text { and } m_{2} \text {-integrated deviations of partial values from }
$$

two samples which are compared with the average values $\bar{x}_{1}$ and $\bar{x}_{2}$.

$$
m_{1}^{2}=\frac{S_{1}}{n_{1}} ; \quad m_{2}^{2}=\frac{S_{2}}{n_{2}} \text {, where } S_{1} \text { and } S_{2} \text {-sample variances ( EG before the }
$$

experiment and EG after the experiment), where the variance is calculated by the formula:

$$
\begin{aligned}
& \mathrm{S}=\frac{1}{n} \sum^{n}\left(\bar{x}_{1}-\bar{x}_{2}\right)^{2} . \text { Thus, } \\
& t=\frac{|69,61-88,93|}{\sqrt{\frac{85,15}{15}+\frac{24,56}{15}}}=\frac{19,32}{7,31} \approx 2,64
\end{aligned}
$$

For the degree of freedom $\boldsymbol{n}_{1}+\boldsymbol{n}_{2}-2$ we calculate $(15+5)-2=28$ and significance levels 0,05 (significance point $\boldsymbol{t}$ - the Student t-test - 2,05). According to our calculations, we 


\section{Arab World English Journal (AWEJ) Special Issue on Covid 19 Challenges April 2021}

received $\boldsymbol{t}_{\text {empirical }} 2,64$, i.e $\boldsymbol{t}_{\text {empirical }}(2,64)>\boldsymbol{t}_{\text {significant }}(2,05)$, indicating the statistical significance of the compared average results of the experimental group before and after the experiment. Therefore, the obtained values of the Student t-test shows that there have been positive changes in the experimental group after the application of the method of forming a culture of working with information. This fact is indicative of the effectiveness of this technique, and, therefore we can say that the experiment is successful.

The researchers also conducted a self-assessment of students of the desired level of formedness and formedness of a culture of working with information by the method of Spearman's rank correlation.

Table 4. Calculation $\boldsymbol{d}^{2}$ for Spearman's rank correlation $\boldsymbol{r}_{\boldsymbol{s}}$ when comparing the average group values of self-assessment of hard and soft skills of future specialists of the experimental group (EG) of the ascertaining experiment

\begin{tabular}{|c|c|c|c|c|c|c|}
\hline \multirow{2}{*}{$\begin{array}{l}\text { Hard and soft } \\
\text { skills }\end{array}$} & \multicolumn{2}{|c|}{$\begin{array}{c}\text { Assessment of the desired level of } \\
\text { culture formedness of working } \\
\text { with information according to } \\
\text { students }\end{array}$} & \multicolumn{2}{|c|}{$\begin{array}{l}\text { Self-assessment of culture } \\
\text { formedness of working with } \\
\text { information }\end{array}$} & \multirow{2}{*}{$\underset{\left(\mathrm{r}_{1}-\mathrm{r}_{2}\right)}{\mathbf{d}}$} & \multirow[t]{2}{*}{$\mathbf{d}^{2}$ (summa) } \\
\hline & $\begin{array}{c}\text { Average group } \\
\text { values in } \%\end{array}$ & $\begin{array}{c}\boldsymbol{r}_{\boldsymbol{I}} \\
(\text { rank })\end{array}$ & $\begin{array}{l}\text { Average group } \\
\text { values in } \%\end{array}$ & $\begin{array}{c}\boldsymbol{r}_{2} \\
(\text { rank })\end{array}$ & & \\
\hline 1. & 83,2 & 3 & 60,3 & 1 & 2 & 4 \\
\hline 2. & 70,3 & 8 & 50,1 & 3 & 5 & 25 \\
\hline 3. & 65,0 & 10 & 49,2 & 4 & 6 & 36 \\
\hline 4. & 56,2 & 13 & 33,1 & 6 & 7 & 49 \\
\hline 5. & 60,3 & 18 & 20,2 & 11 & 0 & 0 \\
\hline 6. & 80,3 & 4 & 18,2 & 14 & -10 & 100 \\
\hline 7. & 50,6 & 14 & 15,3 & 15 & -1 & 1 \\
\hline 8. & 70,8 & 16.5 & 25,3 & 9 & $-2,5$ & 6,25 \\
\hline 9. & 85,3 & 2 & 50,2 & 2 & 0 & 0 \\
\hline 10. & 74,3 & 6 & 20,1 & 12 & -6 & 36 \\
\hline 11. & 75,6 & 5 & 22,2 & 10 & -5 & 25 \\
\hline 12. & 60,8 & 12 & 31,2 & 7 & 5 & 25 \\
\hline 13. & 70,8 & 6,5 & 34,6 & 5 & 1,5 & 2.55 \\
\hline 14. & 69,5 & 9 & 27,8 & 8 & 1 & 1 \\
\hline 15. & 89,1 & 1 & 18,9 & 13 & -12 & 144 \\
\hline \multicolumn{6}{|c|}{ Number of skills $\mathbf{n}=15$} & 454,8 \\
\hline
\end{tabular}

Table 5.Calculation $\boldsymbol{d}^{2}$ for Spearman's rank correlation $\boldsymbol{r}_{\boldsymbol{s}}$ when comparing the average group values of self-assessment of hard and soft skills of future specialists of the control group (CG) of the ascertaining experiment

\begin{tabular}{|c|c|c|c|c|}
\hline $\begin{array}{c}\text { Hard and soft } \\
\text { skills }\end{array}$ & $\begin{array}{c}\text { Assessment of the desired level of } \\
\text { culture formedness of working } \\
\text { with information according to } \\
\text { students }\end{array}$ & $\begin{array}{c}\text { Self-assessment of culture } \\
\text { formedness of working with } \\
\text { information }\end{array}$ & $\begin{array}{c}\mathrm{d} \\
\left(\mathrm{r}_{1}-\mathrm{r}_{2}\right)\end{array}$ & $\mathrm{d}^{2}$ (summa) \\
\hline
\end{tabular}


Arab World English Journal (AWEJ) Special Issue on Covid 19 Challenges April 2021

Formation of the Culture of Working

Markiv, Zarivna, Khymai \& Shalova

\begin{tabular}{|c|c|c|c|c|c|c|}
\hline & $\begin{array}{c}\text { Average group } \\
\text { values in \% }\end{array}$ & $\begin{array}{c}\mathrm{r}_{1} \\
\text { (rank) }\end{array}$ & $\begin{array}{c}\text { Average group } \\
\text { values in \% }\end{array}$ & $\begin{array}{c}\mathrm{r}_{2} \\
\text { (rank) }\end{array}$ & & \\
\hline 1. & 81,2 & 3 & 53.3 & 1 & 2 & 4 \\
\hline 2. & 70,2 & 8 & 40.2 & 6 & 2 & 4 \\
\hline 3. & 49,2 & 14 & 31,3 & 10 & 4 & 16 \\
\hline 4. & 55,3 & 13 & 45,3 & 5 & 8 & 64 \\
\hline 5. & 61,2 & 9 & 18.2 & 11 & -2 & 4 \\
\hline 6. & 79,2 & 4 & 36,3 & 7 & -3 & 9 \\
\hline 7. & 49,7 & 15 & 50,1 & 3 & 12 & 144 \\
\hline 8. & 71,2 & 6 & 32,2 & 9 & -3 & 9 \\
\hline 9. & 84,2 & 1 & 50,6 & 2 & -1 & 1 \\
\hline 10. & 70,3 & 7 & 46,1 & 4 & 3 & 9 \\
\hline 11. & 74,5 & 5 & 35,1 & 8 & -3 & 9 \\
\hline 12. & 59,2 & 11 & 15,2 & 13 & -2 & 4 \\
\hline 13. & 60,3 & 10 & 16,3 & 12 & -2 & 4 \\
\hline 14. & 55,8 & 12 & 10,2 & 15 & -3 & 9 \\
\hline 15. & 81,3 & 2 & 12,3 & 14 & -12 & 144 \\
\hline & \multicolumn{7}{l}{ Number of skills $\boldsymbol{n}=15$} & & & 424 \\
\hline
\end{tabular}

Students of the experimental and control groups assessed the desired level of formedness and culture formedness of working with information on the proposed fifteen hard and soft skills:

Table 6. Self-assessment card of the culture formedness of working with information

\begin{tabular}{|l|l|l|}
\hline № & \multicolumn{1}{|c|}{ Hard and soft skills } & Score \\
\hline 1 & Understanding the content of information and its value effect on people & \\
\hline 2 & $\begin{array}{l}\text { Comprehension of the importance of information for the formation of the mature highly } \\
\text { developed successful personality }\end{array}$ & \\
\hline 3 & $\begin{array}{l}\text { Mastering skills and abilities to plan and meet the requirements for searching, processing, } \\
\text { creating and disseminating information independently }\end{array}$ & \\
\hline 4 & Conducting self-monitoring and analysis of the impact of information on mental health & \\
\hline 5 & Ability to use fact-checking voluntarily & \\
\hline 6 & Formedness of a stable negative attitude to propaganda materials & \\
\hline 7 & Formedness of motivation to check the material in different sources & \\
\hline 8 & Using a "gourmet" method of selecting information & \\
\hline 9 & $\begin{array}{l}\text { Ability to use resources created by professional journalists and in social networks } \\
\text { proportionally }\end{array}$ & \\
\hline 10 & The ability to verify information independently before it's dissemination in social media pages & \\
\hline 11 & $\begin{array}{l}\text { Mastering the technique of self-regulation in stressful situations due to the inconsistency of } \\
\text { information with the individual system of beliefs, values, judgments }\end{array}$ & \\
\hline 12 & Ability to distrust everything that is written & \\
\hline 13 & Efforts to evaluate information as rationally as possible & \\
\hline 14 & Adjustment of the individual condition after reading "heavy" information & \\
\hline 15 & Rest from production and consumption of information & Total score - 15 \\
\hline \multicolumn{2}{|l}{}
\end{tabular}

Spearman's rank correlation coefficient is calculated by the formula: 
$r_{s=1}-\frac{6 \times \sum d^{2}}{n\left(n^{2}-1\right)}$, where $\sum d^{2}-$ the sum of squared values of rank differences, and $n$ number of paired observations. Due to the obtained results of self-assessment we calculate the empirical value $r_{s}$ of experimental group: $r_{s=1-} \frac{6 \times 454,8}{3360}=1-0,812=0,188$

We also calculate similar values of the control group:

$$
\boldsymbol{r}_{s=1-} \frac{6 \times 424}{3360}=1-0,7571=0,242
$$

We compare the results of calculations of the empirical rank correlation coefficient $r_{s}$ of both groups - (0,188 EG), (0,242 CG) and significant $(0,482)$. At the level of statistical significance, 0,05 values of Spearman's rank correlation coefficient are lower than $r_{s}$ significant. It means that the level of students' formedness of hard and soft skills of the culture of working with information by the results of self-assessment is low (insufficient) and goes to 0 in both groups. It also means that the motivation and value component is poorly formed.

\section{Discussion}

The research was aimed at assessing the effectiveness of the proposed model of forming a culture of working with information, as well as collecting and processing data that demonstrate the need for such competence among students, the dynamics of development during the experiment and verification of organizational model effectiveness.

At the ascertaining stage the concept "culture of working with information" was defined by future experts, and measurements of levels of this competence formation were conducted (the level is proved to be low).

As a result of the performance of the formative stage of the experiment (special materials were purposefully selected, trainings on checks of information were used, explanatory work was conducted by teachers, debates and discussions of materials containing hidden manipulative content, post-truth instead of a fact, alternative facts, the substitution of concepts, etc.) competencies of formation of a culture of working with information in the experimental group (25\%) increased compared with the control group $(9.9 \%)$.

At the final stage comparison of the results before and after the experiment was conducted. Insufficient level of the motivational component was revealed (according to motivational criterion); cognitive criterion (the ability to understand the content that forms the skills of the culture of working with information and deepen competencies) showed higher performance in the experimental group the teachers worked with; activity indicators increased when working with students (especially the average).

The results showed positive dynamics and efficiency during distance learning which allowed us to integrate the topics of media literacy, media culture and culture of information consumption in special courses: "Mass media in the world information space" of the Humanities University. At the Technical University, English teachers purposefully offered students to study 


\section{Arab World English Journal (AWEJ) Special Issue on Covid 19 Challenges April 2021}

mass media materials in the classroom. Such tasks aroused students' interest and increased motivation to acquire cultural and informational competence. Discussions in the mode of online conferences (Zoom, Google meet etc.) were used, tests were offered in the Moodle platform where the main university courses are located. It is convenient for teachers and students to work in this way. They coped with the tasks, had the opportunity to help each other during online discussion of the manipulative content of the processed materials, gained experience in factchecking and learned to evaluate information properly. It is easy to understand the core of the competence "culture of working with information", as well as its presence / absence and the dynamics of formation with the help of questionnaires, test blocks and diagnostic questions. Students evaluate the distant learning system positively. The integration of special topics into education courses has strengthened cognitive interest, revitalized the learning process and helped to study media literacy.

It should be noted, that there is a great need to form a culture of working with information in the society of the new type. Thus, the teachers must form the need, show the importance and significance of the culture of working with information in a variety of information, its incredibly large-scale accumulation, widespread and increasing destructiveness due to ignorance and lack of this competence. It is more difficult to form a system of knowledge, skills and abilities, as it could be seen from the experiment, in conditions of distance learning, but the motivation is stronger, and the activity component is more pronounced: it is necessary to work with a lot of miscellaneous information independently.

Thus, let's summarize the results according to the stated criteria:

Motivation criterion is a motivation, awareness with the need and desire to acquire the competence of "a culture of working with information".

Table 7. Comparative analysis of values and motivation criterion of experimental and control groups

\begin{tabular}{|l|c|c|}
\hline \multicolumn{1}{|c|}{ Values } & Experimental group & Control group \\
\hline 1 -st value & 4,5 & 4,4 \\
\hline 2 -nd value & 4,2 & 4,0 \\
\hline $3-$ rd value & 4,1 & 3,9 \\
\hline $4-$ th value & 4,3 & 3,8 \\
\hline $5-$ th value & 3,1 & 2,8 \\
\hline
\end{tabular}

Cognitive criterion is an ability to understand the content that forms the skills of media culture and deepen competencies.

Table 8. Comparative analysis of cognitive criterion values of experimental and control groups

\begin{tabular}{|l|c|c|}
\hline \multicolumn{1}{|c|}{ Values } & Experimental group & Control group \\
\hline $1-$ st value & 3,9 & 2,9 \\
\hline $2-$ nd value & 4,0 & 3,4 \\
\hline $3-$ rd value & 3,7 & 2,5 \\
\hline $4-$ th value & 3,8 & 3,0 \\
\hline $5-$ th value & 3,7 & 3,2 \\
\hline
\end{tabular}


Arab World English Journal (AWEJ) Special Issue on Covid 19 Challenges April 2021

Formation of the Culture of Working

Markiv, Zarivna, Khymai \& Shalova

Activity criterion is an ability to apply knowledge in practice and use them even in non-standard situations.

Table 9. Comparative analysis of activity criterion values of experimental and control groups

\begin{tabular}{|l|c|c|}
\hline \multicolumn{1}{|c|}{ Values } & Experimental group & Control group \\
\hline 1 -st value & 3,9 & 2,4 \\
\hline 2 -nd value & 3,8 & 2,5 \\
\hline 3 -rd value & 3,4 & 2,3 \\
\hline $4-$ th value & 3,3 & 2,3 \\
\hline 5 -th value & 3,1 & 2,6 \\
\hline
\end{tabular}

It should be concluded, that the values are higher in the group in which this competence has been formed intentionally.

The data obtained as a result of mathematical processing of values of control diagnostic check values, give grounds to say that students' interest in improving a culture of working with information begins to appear even under conditions of experimental training. The study showed that after the scientific experiment having been done, the dynamics of the levels of a culture of working with information is obvious, in particular, the average value has increased.

The problem of the study was to show the importance of forming a culture of working with information among the students during distance learning, which means the ability to evaluate and perceive information properly, prevent manipulation and distinguish truth from falsehood.

It was necessary to perform the following tasks to perform it: to analyze the need of the formation of skills of the culture of working with information, to assess the feasibility of the developed model of its formation and to conduct an experiment to determine effectiveness.

The researchers proved the sudents' need to form skills of media culture and proper information consumption in the process of research, especially in the distance-learning mode. The pedagogical environment is decisive for their formation of such skills. Even e-learning allows you to do it with the right methods and tools. After all, it is important to model the need for such competence and to show its implementation to solve problematic professional problems. The teacher's task is to encourage students to use the acquired knowledge, skills and abilities in consuming information not only if it is needed, but also in everyday life. It is necessary to convince students of the importance of critical attitude to information, verification of authenticity, use of fact-checking techniques, etc. Students' interest in improving the culture of working with information begins to be discovered in the conditions of experimental learning.

Writers estimated the feasibility of using an organizational model for the formation of this competence which includes the following components: 1) purpose and goals - to encourage students' desire and readiness to form a culture of working with information; 2) pedagogical conditions - comprehensive motivation of educational activities of future professionals to the formation of cultural competence within working with information; structuring the content of professional training for the formation of a culture of working with information; argued the choice of optimal methods; 3 ) criteria of formation - value and motivational, cognitive, activity 


\section{Arab World English Journal (AWEJ) Special Issue on Covid 19 Challenges April 2021}

criteria. We substantiated theoretically and confirmed experimentally that the effectiveness of the formation of the competence "a culture of working with information" is achieved through the implementation of a combination of these three components providing the formation and development of relevant skills. E-learning is also suitable for the implementation of this model.

Researchers conducted a pedagogical experiment on the formation of a culture of working with information and evaluated its results according to the proposed criteria: value and motivational, cognitive, activity criteria. All criteria showed an order of magnitude higher value in the experimental group than in the control group. Thus, the experiment proved that humanities and technical students are equally ready to obtain this type of knowledge. The main thing is to choose the material for processing correctly and purposefully, to conduct disputing lectures, discussions, trainings, etc. It is also important to take into account students' self-assessment of the level of their skills to search, analyze, process and disseminate information.

Authors suggest that it might be worth beginning to form a culture of working with information by integrating relevant topics and tasks for discussion into learning courses. We have shown, though incomplete, but an effective mechanism for how to do it practically in the conditions of distance learning. Of course, this technique needs to be improved, and also develop more criteria, involve specialists of different disciplines for the implementation of the developed model into practice.

The uniqueness of the study is that the very formation of a culture of working with information is a pedagogical issue because it is possible to form certain skills and abilities and explain their importance only during training. Pedagogical conditions included motivation to the formation, the content of training future professionals, pedagogical experiment and evaluation criteria. The study showed achievement. Therefore, the organizational model should be recommended for implementation at other faculties, because it is important for everyone to be able to assess, perceive, assimilate, create and disseminate information properly regardless of speciality.

In the future, we are planning to design a special course on information production and consumption which is going to be subject-oriented on the formation of a culture of working with information.

\section{About the Authors}

Oleksandra Markiv is a Ph.D. in Pedagogic Sciences, an Associate professor of the Department of Journalism of National Pedagogical Dragomanov University. Now she is currently working on the problem of media literacy and health culture as a necessity of educational space in modern society. ORCID ID https://orcid.org/0000-0001-5720-650X

Oksana Zarivna is a Ph.D. in Pedagogic Sciences, an Associate professor of the Department of English for Engineering \# 2 of National Technical University of Ukraine "Igor Sikorsky Kyiv Polytechnic Institute". Now she is currently working on the problem of critical thinking in teaching English at a technical university. ORCID ID https://orcid.org/0000-0002-9821-4482 
Arab World English Journal (AWEJ) Special Issue on Covid 19 Challenges April 2021

Markiv, Zarivna, Khymai \& Shalova

Nataliia Khymai is a Senior Lecturer of the Department of English for Engineering \# 2 of National Technical University of Ukraine "Igor Sikorsky Kyiv Polytechnic Institute". Now she is currently working on the problem of improvement of e-learning tools during a pandemic. ORCID ID https://orcid.org/0000-0002-2625-7301

Natalia Shalova is a Senior Lecturer of the Department of English for Engineering \# 2 of National Technical University of Ukraine "Igor Sikorsky Kyiv Polytechnic Institute". Now she is currently working on the problem of formation of learning strategies within teaching English for ESP at the university. ORCID ID https://orcid.org/0000-0003-4719-727X

\section{References}

Adams, P. (2018). The upside of "fake news": renewed calls for media literacy. Social Education, 82(4), 232-234. Retrieved from https://www.socialstudies.org/system/files/publications/articles/se_8204232.pdf

Blystiv, O., \& Halaz, L. (2015). Vzaiemozviazok informatsiinoi kultury ta yakosti navchalnoho protsesu [Interrelation between information culture and the quality of educational process]. Visnyk Natsionalnoho universytetu «Lvivska politekhnika», 2(815/3), 15-21. Retrieved from http://science.lpnu.ua/uk/semi/vsi-vypusky/vypusk-2-nomer-81532015/vzayemozvyazok-informaciynoyi-kultury-ta-yakosti

Blyzniuk, M., \& Koliada, M. (2000). Formuvannia informatsiinoi kultury osobystosti [Formation of personality media culture]. Kyiv: Libra.

Buckingham, D. (2003). Media Education: Literacy, Learning and Contemporary Culture. Cambridge, UK: Polity Press.

Bulger, M., \& Davison, P. (2018). The Promises, Challenges, and Futures of Media Literacy. Journal of Media Literacy Education, 10(1), 1-21. DOI: https://doi.org/10.23860/JMLE2018-10-1-1

Cubbage, J. (2018). Media literacy in higher education environments: An introduction. In Handbook of Research on Media Literacy in Higher Education Environments (pp. 1-24). IGI Global. DOI: https://doi.org/10.4018/978-1-5225-4059-5.ch001

Dachkovska, M. (2016). Dlia tanho potribni dvoie: chy ye vzaiemodiia mizh osvitianamy ta mediaindustriieiu? [Tango requires two things: is there an interaction between educators and the media industry?]. Retrieved from https://ms.detector.media/zhurnalistskaosvita/post/17786/2016-11-09-dlya-tango-potribni-dvoie-chy-ie-vzaiemodiya-mizhosvityanamy-ta-mediaindustriieyu/

Eismunt, V. (2016). Instrumenty faktchekinhu: yak profesiino vidrizniaty brekhniu vid pravdy [Fact-checking tools: how to distinguish lies from truth professionally]. Retrieved from https://imi.org.ua/articles/instrumenti-faktchekingu-yak-profesiyno-vidriznyati-brehnyuvid-pravdi-i407

Higdon, N. (2020). The Anatomy of Fake News: A Critical News Literacy Education. Oakland, California: University of California Press. DOI: https://doi.org/10.2307/j.ctv1503gc8

Jolls, T., \& Wilson, C. (2014). The Core Concepts: Fundamental to Media Literacy Yesterday, Today and Tomorrow. Journal of Media Literacy Education, 6(2), 68-78. Retrieved from https://digitalcommons.uri.edu/jmle/vol6/iss $2 / 6$

Levshyn, M. (2002) Pedahohichna sutnist poniattia "informatsiina kultura osobystosti" [Pedagogical essence of the concept "media culture of personality"]. Vyshcha osvita Ukrainy, 3, 67-74. Kyiv: Lira-K. 
Arab World English Journal (AWEJ) Special Issue on Covid 19 Challenges April 2021

Markiv, Zarivna, Khymai \& Shalova

Markiv, O. (2018). Formuvannia v maibutnikh zhurnalistiv kultury roboty z informatsiieiu v umovakh hibrydnoi viiny [Forming the culture of working with information in a hybrid war among future journalists]. In V. Zhadka, (ed.), Hibrydna viina i zhurnalistyka. Problemy informatsiinoi bezpeky (pp.290-304). Kyiv: NPU imeni M. P. Drahomanova. Retrieved from http://enpuir.npu.edu.ua/handle/123456789/25594

Markiv, O., \& Zarivna, O. (2019). Mediahramotnist i kultura zdorovia yak neobkhidnist osvitnoho prostoru (na prykladi studii inozemnoi movy i zhurnalistyky) [Media literacy and health culture as a necessity of educational space (on the example of foreign language studios and journalism)]. Naukovi zapysky Natsionalnoho universytetu «Ostrozka akademiia», 6, 168-172. Retrieved from http://enpuir.npu.edu.ua/handle/123456789/26111

Mason, L. E., Krutka, D., \& Stoddard, J. (2018). Media Literacy, Democracy, and the Challenge of Fake News. Journal of Media Literacy Education, 10(2), 1-10. DOI: https://doi.org/10.23860/JMLE-2018-10-2-1

McDougall, J. (2019). Media Literacy versus Fake News: Critical Thinking, Resilience and Civic Engagement. Medijske studije, 10(19), 29-45. DOI: https://doi.org/10.20901/ms.10.19.2

Petryk, V. (2009). Sutnist i osoblyvosti provedennia spetsialnykh informatsiinykh operatsii ta aktsii informatsiinoho vplyvu [The essence and features of special information operations and actions of information influence conducting]. Suchasni informatsiini tekhnolohii u sferi bezpeky ta oborony, 3(6), 71-75. http://nbuv.gov.ua/UJRN/sitsbo_2009_3_15

Plakhta, D. (2017). Chomu vazhlyvo buty mediahramotnym, abo Yak vyrobliaty u sobi informatsiinu «imunnu systemu» [Why it is important to be media literate, or How to develop an information "immune system"]. Den. Retrieved from https://day.kyiv.ua/uk/blog/suspilstvo/chomu-vazhlyvo-buty-mediagramotnym

Pocheptsov, H. (2013). Smyslovi ta informatsiini viiny: poshuk vidminnostei [Semantic and information wars: the search for differences]. Detektor media. Retrieved from https://ms.detector.media/manipulyatsii/post/4569/2013-03-17-smyslovi-tainformatsiyni-viyny-poshuk-vidminnostey/

Schultz-Jones, B. (2016). Teaching the Ethical Use of Information as an MIL Skill. In S. Ingvaldsen, \& D.Oberg, (Ads.), Media and Information Literacy in Higher Education: Educating the Educator (pp. 13-35). Elsevier BV. DOI: https://doi.org/10.1016/B978-008-100630-6.00002-3

Shelestova, A. (2016). Informatsiina kultura [Media culture]. Ukrainska bibliotechna entsyklopediia. Retrieved from https://ube.nlu.org.ua/

Simmons, T. (2019). Media Literacy and Fake News: How Media Literacy Can Curb the Fake News Trend. In Management Association, I. (Eds.), Journalism and Ethics: Breakthroughs in Research and Practice (pp. 163-176). IGI Global. DOI: http://doi:10.4018/978-1-5225-8359-2.ch011

Šuminas A., \& Jastramskis D. (2020). The importance of media literacy education: How Lithuanian students evaluate online news content credibility. Central European Journal of Communication, 13, 230-248. DOI: https://doi.org/10.19195/1899-5101.13.2(26).5

Tornero, J. M. P., Tayie, S. S., Tejedor, S., \& Pulido, C. (2018). How to confront fake news through news literacy? State of the art. Doxa Comunicación. Revista Interdisciplinar de Estudios de Comunicación y Ciencias Sociales, 26, 211-235. Retrieved from https://repositorioinstitucional.ceu.es/bitstream/10637/9499/3/How_JMPerez\%26SSamy\%26STe jedor\%26CPulido_Doxa_Comuni_2018_EN.pdf 